\title{
IMPROVING THE EIGHT GRADE STUDENTS' COMPETENCE IN USING QUESTION TAGS THROUGH DISCUSSION METHOD AT SMP DELI MURNI MEDAN
}

\author{
Yolenta Wea, Viator Lumban Raja, Novalina Sembiring \\ Catholic University of Saint Thomas \\ Email: novalina_sembiring@ust.ac.id
}

\begin{abstract}
This research is conducted in order to improve the eight grade students' competence in using question tag through Discussion Method at SMP Deli Murni Medan. It also helps the English teacher of the eight grade students of SMP Deli Murni Medan to manage learning and teaching activities in the classroom. In conducting this research, the writer used Classroom Action Research (CAR) as the method of research. Thisresearch consists of two cycles and each cycle consists of four steps, they were planning, action, observation and reflecting. The data were in the form of qualitative and quantitative data. The qualitative data analyzed the learning process. The quantitative data counted the students' score in pre-test and post-test. The result of this research shows that in teaching question tags through Discssion Method at the eight grade students of SMP Deli Murni Medan could improve their competence in using question tags. Moreever, the students' achievements in pretest and post-test showed a significant improvement. The total score of quantitative data in pre-test was 1998 with the mean score 54, while the total score in formative test was 2630 with the mean score 71,08 and the total score of post-test was 3004 with the mean score 81,18 . From the result, the writer concluded that Discussion Method could improve students' competence in using question tags.
\end{abstract}

Keywords: Discussion Method, Question Tags

\section{INTRODUCTION}

Language is a system of communication used by a particular country or community. By using language, people are able to convey their messages, to express their idea in oral or written language so that they can communicate with each other. English is one of the important languages and used by a lot of people around the world. The reasons are: firstly, English functions as a scientific key, because many books and sientific texts are written in English. Secondly, because English is so widely spoken that it has often been referred to as a global language. While English is not an official language in most countries, it is currently the language most often taught as a foreign language or second language around the world. In Indonesia, English as the first foreign language is taught in the schools since English has become an international language and used by most nations in the world. In the globalization era, the acquisition of English is very important, because it is used as a medium of communication both, in oral and written forms. English is also one of the ways of solving the miscommunication between Indonesian and people from other countries.

The aim of learning English is to develop spoken and written communication capibility which is reflected in listening, speaking, reading, and

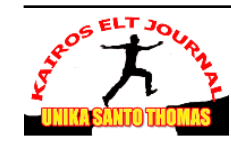


writing. These four skills should be involved by the teacher in process of teaching and learning in a classroom. In addition, having those skills, the students should have knowledge of language components. The components are vocabulary, pronouncation, and grammar. Each of the langauge skills has a relationship to each other. Grammar is the central think to be mastered, especially by the students of junior high school. They should know the grammar well in order that they know how to produce grammatically correct and semantically acceptable sentences. If someone says "My brother is pregnant", this sentence is grammatically correct, but not semantically acceptable because only female can be pregnant. Grammar is the rules of how to arrange good sentences. Therefore one has to mastery the English grammar first in order to communicate well.

According to Geoffrey, et al. (2000:4) Grammar is a mechanism for putting words together, but we have said little about sound and meaning. We can think of grammar as being central part of language which relates sound and meaning. The meaning of a message conveyed by language has to be converted into words put together according to grammatical rules and these words are then conveyed by sound.

According to Byrd and Benson (2001:191) one of the grammar topics is questions tag. Tag questions are formed by adding a "tag" to a statement. It means that a question is added in a statement or sentence, and always it is added at the end. Primarily, question tagsare used to seek confirmation or agreement in a statement or sentence.

Question tags are the grammar topic given to students at the school. It is basic knowledge of English that should be mastered by them. By learning question tag, the student can enrich their competence in English, especially grammar. Also, it can help the students to improve their speaking skills because the form of question tag is often used in simple short conversation. It is a common practice in conversation to make a statement and ask for confirmation: as "it's very hot, isn't it?" the latter part ('isn't it?") is called a question tag.

For example: 1) It's raining, isnt't it?

2) She can swim well, can't she?

3) You aren't busy, are you?

Sentence (1) and (2) are affirmative in simple present tense, so the tag is negative with its pronoun. Sentence (3) is negative in present tense, so the tag is positive with its pronoun.

There are some exceptions in question tag which may be confusing.

For example: 4) I am a police, aren't I?

5) Everybody likes singing, don't they?

6) Nobody is perfect, aren't they?

In sentence (4) the tag should be "amn't I" but it is changed to "aren't I" because it is hard to pronounce two nasal sounds together at once. In sentence (5) pronoun "everybody" is considerd "all", that is the tag is "they". In sentence (6) negative word "nobody" is also considered all, so the tag is positive with they its pronoun.

Based on the writer's preliminary observation at SMP Deli Murni Medan, the writer found that the students got some problems in learning grammar. In fact, some students have difficulties in understanding English language. Their English teacher Mrs. R. Sipayung also said it is difficult for the students to answer her

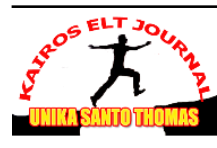


question especially in question tag. According to her it is because they do not know the rules of question tag correctly, even though she had explained about it many times. Thus, the writer interested to give variation in teaching question tag through discussion method.

According to Fathul Aziz (2013: 11) Discussion Method is a good method in the learning process. In his research entitled Improving "Speaking sklill by Using Discusssion method" to the second grade students of the MA, Fajrul Hidayah, Batujai Lombok Tengah, he found out that the result of the students test showed that the students' speaking ability improved from 55 in average to 75.85. The students also felt challenging to speak and share their ideas, and made them enthusiastic to learn. They could explore their opinions in front of the class without feel afraid, they felt very confidence and comfortable in their performance.

Based on the preliminary research and the problem above the writer intersted to try the discussion method in improving the students' competence in question tag. Thus, the writer conducted classroom action research entitled "improving the eighth grade students' competence in using question tags through discussion method at SMP Deli Murni Medan."

\section{LITERATURE REVIEW}

\subsection{The Concept of Grammar}

Grammar is usually considered one of the language components besides the vocabulary and sound system which students should acquire. According to Diane (2003:11) knowing grammar means understanding what the text means correctly. Grammar gives language users the control of expression and communication in everyday life.It regulates how to form phrases sentence and discourses. Every sentence we make should be in accordance with grammatical rules. Therefore grammar deals withthe form of sentences and smaller units such as clauses, phrases and words.

(1) He go to church last Sunday.

(2) The boy ran out from home.

(3) The book is in the table.

The underlined words above are not accepted informal English because the are not used accordingthe grammatical rules. The verb go should be went because of the adverb last Sunday. The phrasal verb ran out should be ranaway because it shows a place. The preposition in should be on because a table has no space inside.

Although those sentence are grammatically wrong they are still understand able using communication. But in written communication such athing is not allowed because written communication requires exact meaning. Readers can not ask or clarify something unclear in the written form since the writer is not present in front of them.

Mastery over words helps speakers to communicate their emotions and purpose more effectively. Otherwise, communication can sound like a toddler getting frustrated because he or she does not have many words to express his or her thoughts well. Moreover, grammar also gives effect in written communication. Written communication skills with grammatical precision evince professionalism.

According to Penny (1991:76) grammar is one of the important things in English because it is not just to make the sentence good but also it will refer to its meaning. A knowledge of grammar in this sense is not just concerned with rules for

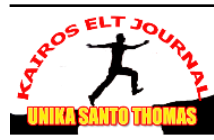


what can and can't be done with the organization and use of words in English sentences, but also with the way written English function. Therefore, to write or speak in a clearer and more effective manner, people have to study grammar. For the people who have unconscious knowledge of grammar, it may be sufficient for simple language use. But the people who wish to communicate in the artistic manner with well-defined structures must go for the greater depth of understanding and proficiency what the study of grammar offers.

When teaching a language, teachers actually have two purposes; insure fluency and accuracy in all language skills. Fluency is the ability to speak fluently whereas accuracy is ability to speak with correct grammatical structures, such as the using of verb forms correctly, phrasal verbs, prepositions, etc.

\subsection{The Concept of Sentence}

According to Frank (1972:1) English sentence consists of predications something is said, or predicated about a subject. The main grammatical divisions of a sentence are therefore the subject and the predicate.

Example: The girl bougth some flowers in the market.

This sentence consist of subject ( the girl) and predicate (bought some flowers in the market) which consist of direct object and adverbial.

Spring (1989:34) states sentences are divided into four categories: simple sentences, compound sentences, complex sentences, and compound-complex sentences.

1. Simple Sentences is a simple sentence contains one independent clause. Example: The earth is round (dependent clause).

2. Compound Sentences is compound sentence contains two independent clauses. A coordinating conjuntion (for, and, nor, but, or, yet) often links the two independent clauses and is preceded by a comma. Example: He likes coffee, but I do not. "He likes coffee" (dependent clause), "I do not" (independent clause).

3. Complex Sentence is contains one independent clause and one or more dependent clauses. A complex sentence will include at least one subordinating conjunction. Example: I do not want to go outside because it is raining. "I do not want to go outside" ( independent clause), "it is raining" (dependent clause).

4. Compound -Complex Sentence is a compound-complex sentence combines complex sentence and compound sentence forms. A compound-complex sentence contains one or more independent clauses and one or more dependent clauses. Example: He found a lot of expired food, but he didn't get rid of it immediately. "He found a lot of expired food" (dependent clause), "he didn't get rid of it immediately" (independent clause).

On the other hand Wren and Martin (1989:1) state that a sentence can be classified into four kinds.

1. Declarative sentenceis a sentence that makes a statement.

2. Interrogative sentenceis a sentence that asks a question.

3. Imperative sentence is a sentence that express a command or an entreaty.

4. Exclamatory sentence is a sentence that express strong feeling.

\subsection{Question Tag}

Azar (1989:16) says question tag is question added at the end of the sentence.A speaker uses question taq chiefly to make sure their informaion is

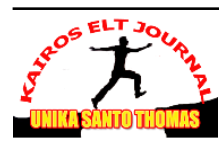


correct or to seek agreement. Question tags are the small questions that often come at the end of sentences in speech, and sometimes in informal writing. Question tags have various form, meaning and uses. They are formed by adding a tag conisting of a finite verb and a pronoun.

A : The book costs expensive, doesn't it?

B : Yeah, I suppose so

The taq usually has diffrent polarity from the rest of the clause. Such questions normally expect that the information will be confirmed.

If the tag is combined with falling intonation, this expectation is even stronger than if it is combined with rising intonation. Normally we use negative question tag after a positive sentence. If the auxiliary verb in the sentence is positive, the tag is negative.

You are Spanish, aren't you ?

1. If the auxiliary verb in the sentence is negative, the tag is positive.

You are not Spanish, are you ?

2. If the verb is not comulative, we use other auxiliaries according to the tense being used.

Birds fly. don't they?

Since the question tags areusually used in spoken English, intonation accompanies descriptive norms. Soars \& Soars (2000:115) say the meaning of question tags is dependent on intonation; If the tag falls, it implies expectation of agreement, while a rise shows that the speaker knows the answer, but not absolutly sure. They also state in a sub sequence point that question tags can be used with negative to make a polite request or ask for help.

Thomson and Martinet (1993:113-114) classify question tags under two main headings according to their function, they are asking for agreement, and confirmtion. After a discussion of how they are formed, i.e. an affirmative statement is normally followed by a negative tag, and the other way around, they describe patterns of intonation that will determine the functions. In a successive point, they list the charactheristic of comment tag, which may indicate among other things interest, surprise, delight, anger, suspicion, disbilieve or nothing a fact.

\subsubsection{The Pattern of Question Tags}

According to Fuchs and Bonner (2000:91-92) if the main clause is negative, the tag is affirmative; if the main cluse is affirmative, the tag is negative, the tag consists of pronoun and finite verb according to the tense being used. The statement containing word such as neither no (adjective), none, no one, nobody, nothing, hardly, ever, seldom, are treated as negative statements and followed by an ordinary interrogative tag.

The basic structure is:

\begin{tabular}{|l|l|}
\hline$(+)$ positive statement & $(-)$ negative tag? \\
\hline Snow is White, & Isn't it? \\
\hline (-) negative statement & $(+)$ positive tag? \\
\hline You don't like me, & do you? \\
\hline (+) positive Statement & $(-)$ negative tag? \\
\hline John was sick & Wasn't he? \\
\hline$(-)$ negative Statement & $(+)$ positive tag? \\
\hline We do not hate them & do we? \\
\hline
\end{tabular}




\begin{tabular}{|l|l|}
\hline$(+)$ positive statement & $(-)$ negative tag? \\
\hline He is coming today & Isn't he? \\
\hline
\end{tabular}

Sentences using question tag should have the main caluse seperated from the tag by a coma. The sentences will always end with a question mark, and we have to use the same auxiliary verb as in the main clause.

There are special rules in question tag:

1. Subject from the presceding statement is repeated with the form personal pronoun in the tag.

e.g $\rightarrow$ Anton will be here, wont he?

$\rightarrow$ The students are lazy to do the homework, aren't they?

2. Statement with subject everybody, everyone, everything, anybody, anyone, nobody, no one, is repeated in the tag with the pronoun'they'.

e.g $\rightarrow$ Everybody watched the movi, didn't they?

$\rightarrow$ No one cares of me,do they?

3. For command and request, the tag uses the expression' will you?

e.g $\rightarrow$ Come here, will you?

$\rightarrow$ Be quite, will you?

$\rightarrow$ don't be lazy, will you?

$\rightarrow$ please dont go, will you?

4. For invitation (command and request) beginning with the words let us/let', the tag uses the expression' shall we?

e.g $\rightarrow$ Let's see the movie, shall we?

$\rightarrow$ Let us pay attention to the teacher's speaking, shall we?

The positive statement of I am' necessiates the tag in aren't I?

e.g $\rightarrow$ I am pretty, aren't I ?

$\rightarrow$ I am not guality, am I?

5. Statements containing words such as, never, seldom, rarely, barely, hardly, Few, little are considered as negative statement, therefore the tag shoul be in positive.

e.g $\rightarrow$ You seldom have your hair cut, do you?

$\rightarrow$ She never seems to care, does she?

$\rightarrow$ she can hardly see us witout her glasses, can she?

\subsection{The Concept of Discussion Method}

\subsubsection{The Definition of Discussion Method}

According to Latchanna \& Dagnew (2009: 103-105) learning English effectively is affected by method, teacher's attitude, belifes and also by students' motivation to learn. Great importance in language acqusition is played within the classroom environment. Students gain positive or negative feelings toward learning depending on such elements. A good teacher tries to differentiate strategies in their classes. Instead of applying just individual learning, teachers may use cooperative learning.

Cooperative learning is intended to involve every student in a certain topic. In the group discussion each student is requared to participate by giving their opinion idea or comment on the topic under discussion. Because of the increasing responsibility to participate, sutudents gain confidence in using the target language. Students are responsible managers of their own learning. 
Keeping students active and up to pace teachers may use group discussion methods. Comunicative activities would keep students' interaction to maximum by exchangeing information, giving opinion through cooperative work. Bydiscussion method, students' develop speaking skills, aquire fluency and develop postive effect towards frendship.

According to Westwood (2008:34) the behavior of teachers and learners in the classroom shoud be as similiar as posible to the behavior of people in the "real world" outside the classroom. Apart from being active in the classroom, students are free to give their opinion. Dicussion may be conducted by small group and it is very important to define that small group consists of (4-5) students. Working in group not only increase students' active participation but it also encourages social skill development, and enhances communication and increases independence.

In addition Badache (2015:232) states disccussion method is an instruction method where learners of different level form small group and work together towards a specific objective. Through good discussion a communication process happends and is facilitated. Every shy or positive students takes parts in communicative activities. In students-centered classes teachers role is less dominant than in other methods. Students know what they want to learn and teacher should help them make their goals. Becuse of the increasing responsibility of taking part in a discussion, students feel comfortable and confident in using that type of language that they intend to learn.

In discussion method, students become the center of learning, and the teacher justsupervises and facilitates or moderatesthe discussion. This method can increase self cofidence of the students to comment or to give an idea on the topic being taught. Therefore, discussion method intends to make the students active to participate in the learning. Since a group consists of 4-5 students only, each member of the group will certainly participate seriously to show to other groups that their groups can answer the questio under discussion. This is also one way to declare that their group exsists.

\subsubsection{The Procedures of Discussion Method}

A sucessfull discussion does not just happen, it demands that the instructor be well prepared. To help us to prepare for a class discussion, common concerns and problem are listed below with the sugesstions for how to deal with each. According to Schwartz (2013:1-4) there are some procedures in the discussion method they are elaborated as follows:

\subsubsection{Planning the Discussion}

1. Divided class into pairs or small groups

Divided the students into some small groups (the size of the class will influence the size and number of the small groups. Teacher can divide the students groups based on the absence or anything else.

2. Define the objective of the discussion group

Teacher can relieve anxiety by letting students know that he do not expected everyone to speak everytime. Emphasize that they are not expected to "perform", but rather, share their opinions and observations. It is important that teacher acknowledge the students fear and nervousness.

3. Explain the discussion format to the class

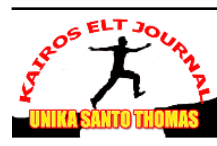


Let the students know if the teacher require them to bring prepared material to class or wether teacher will focus on a number of prefiously handed-out questions or a particular theme. Change discussion formats frequently to ensure that students do not lose interest.

4. Define terms and states assumptions

The participant of the discussion must agree on defenitions of terms and assumptions so that everyone is starting from the same point. The teacher should watch for terms that may need defenition and assumptions that may be implicit, but not stated.

\subsubsection{Generating Discussion}

1. Asking qestions

Ask students a head of time (in a previous class) to prepare one or two questions about their reading. Then ask them to write down their freinds' questions.

2. Some reasons for asking qauestions

Teacher gives some questions to the students to diagnose students difficulties, to introduce a topic, to stimulate analytical thinking, to stimulate analytical thinking, to give direction to problem solving, to encourage imaginative thinking, to help students discover connections between concepts and ideas ( e.g., to link cause and effect) and to promote interest and encourage the application of what has been learned by the students.

3. Finding illustrative quotations

Teacher asks the students to point out qoutations they especially like or dislike, to find out a quotation from the text that best illustrare the major of hte piece and to select a quotation from the assigned reading.

4. Break the class into smaller groups

Some students find small groups less threathening and, therefore, are more likely to enter into the discussion. In order to make this method effective, however students must be given a clear task and a definite amount of time in which to complete it. Finally, they must be ask to use their point of view.

\subsubsection{Formal Debate}

While the effectiveness of this strategy depends on the dynamics of the group. The students select one or the other side of two opposing opinions, then they must defend their point of view.

\subsubsection{Maintaining Discussion}

1. Control excessive talkers

Teacher does not let one or two students monopolize the discussion. Do not call on the "talkers" first, wait to see if someone else raises a hand or volunteers comment. Solicit responses from the "nontalkers" be alert to nonverbal cues indicating tha they have something to say, and then: "Did you want to say something....?" or, "Let's hear from some of you who have not said anything yet." Chose one students to see who is talking often, this will make both the "talkers" and the "nontalkers" modify their behavior.

2. The discussion that goes off track 
If the process of the discussion goes off track, teacher should stop and ask the students to summarize the discussion up to that point helps them to re-focus the group.

3. Instructor's role as group leader

Teacher should know his students, start the discussion with a topic that the students can relate to. Be patient, try not to monopolize the discussion. Listen, discussion are rarely beneficial when a leader does not listen to the contributions of the participants. Hear the students out and concentrate on the points they are trying to make as much as on the points you want to make. Teacher should relate his own experience to facilitate the process o discussion. Inquire, ask the students to elaborate, clarify, expand, explain, explore, etc. Paraphrase, summarize the students ideas with your own words. Relate the concepts and ideas, the teacher can ask participants to compare ideas or concepts brought out in the discussion, or use analogies of illustrative anecdotes to relate ideas. Be accepting rather than judgement or evaluative, try to focus on the correct answer but do not judge the students if they make the wrong answer.

\subsubsection{Concluding the Discussion}

Good discussion end with a summary so that students know the important point that have been covered. In addition to showing students why the discussion is improtant to their learning, a summry provides an opportunity to fill in points not covered, and to praise the class for the quality of their response.

\subsubsection{Advantages Of Discussion Method}

According to Dushi (2012:1) there are several adventages of discussion method:

1. Emphasis on Learning instead of Teaching

Discussion method emphasies pupil-activity in the form of discussion, rather than simply telling and lecturing by the teacher. Thus, this method is more effective.

2. Participation by Everybody.

In this method, everybody participates in the discussion, and therefore they think and express themselves. This is a convincing way of learning.

\section{Development of Democratic way of Thinking.}

Everybody cooperates in the discusssion, and the ideas and opinions of everybody are respected. Thus, there is a development of democratic way of thinking and arriving at a decision.

\section{Training in reflective Thinking}

Students, during the course of discussion, get traning in reflective thinking, which leads to deeper understanding of the historical problem under discussion.

\section{Traning in Self- Expresiion.}

During discussion, everybody is required to express his ideas and opinions in a clear and concise manner. This provides ample apportunities to the students for raning in self-expression.

\section{Spirit of Tolerance is inculcated}

The students learn to discuss and differ with other members of the group. They learn to tolerate the the views of others even if they are unpleasent and contradictory to each other views. Thus, respect for the view points of others is developed.

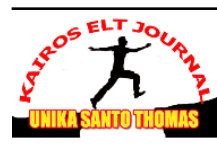




\section{Learning is made Interesting.}

History is considered to be a dry subject. The learning of history is made interesting through Discussion Method. More effective learning is possible when the students discuss, criticise and share ideas on a particular problem. Active participation by the students in the discussion makes learning full of interest for the students. This also ensures better and effective learning

\section{RESEARCH DESIGN}

There are many kinds of of research design in conducting a research. A research method used in this study is classroom action research. Since this researchis intended to the matter of problem- solving and the main purpose is to improve students' competence in question tag through discussion method.Therefore, the kinds of the data to be collected are quantitative and qualitative data. The quantitative data is the test given to the students before and after the application this method in teaching question tag. Where, the qualitative data are obtained during the learning- teaching process. The quantitative data will be collecting by test which consists of 30 questions 20 questions are multiple choice and 10 questiona are essay test. The qualitative data are taken from the observation sheets, questionaries and field notes.

This study involved into four phases in each cycle which were essential as proposed by Kemmis and McTaggart (in Burns,2010:7). Those phases are planning, acting, observing, and reflecting. Each cycle has three meetings. The action that the teacher do in the first cycle influences the second cycle because it is needed to improve what missing in the firct rvcle It make the teacher prepare the action well so that the learning at

The model of Classro crac 1

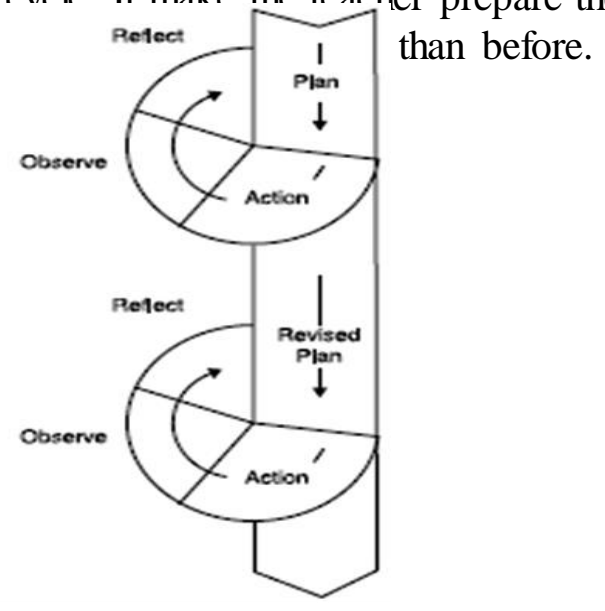

\section{Figure 1. Cyclical Classroom Action Research (CAR) model based on Kemmis and McTaggart in Burns (2010:9)}

The following phases are describe as follows:

1. Planning

Planning is the first phase. In this phase, the writer will identify a problem or issue and develop a plan of action in order to bring about improvements in a specific area 
of the research context. This is a forward-looking phase where the writer considers about what kind of investigation is possible within the realities and constraints of her teaching situation and what potential improvements she thought possible.

The writer will use the syllabus from SMP Deli Murni Medan to support the writer make the lesson plan in supporting the teaching and learning process.

2. Action

The actionis the process of doing what the writer planned before teaching. In this phase, the writerintroduce the topic to the studentsand explain the material.

3. Observation

This phase involve the writer in observing systematically the effects of the action and documenting the context, actions, and opinions of those involved. It is data collection phase where the writer collects information about the condition in the class while the teaching and learning process is running.

4. Reflection

At this point, the writer will reflect on, evaluate and describe the effects of the action in order to make sense of what has happened and to understand the issue more clearly. The scores of the test will be analyzed to know the improvement of the application of metacognitive. The writer willdecide to do further cycles of Classroom Action Research (CAR) to improve the situation if the first cycle has not yet achieved the target.

\section{DATA ANALYSIS AND FINDINGS}

\subsection{Data Analys is}

This study was analyzed by using quantitative and qualitative anaysis. The quantitative data were taken from student's score on the pre-test, formative test,and post test. While the qualitative data were taken from observation sheet, field notes, and questionnnaire. The writer had done the study within two cycles. The first cycle was conducted in three meetings and the second cycle was conducted in three meetings as well. Thus, totally there were six meetings in this study, excluded pretest and pos test.

The data were taken only from one class of SMP Deli Murni Medan.

The class was VIII-B which concisted of 37 students. No students were absent from the first meeting until the last meeting. Therefore,the data in this study concern with the whole students in that class.

\subsubsection{Diary Notes}

\section{Thursday, September $14^{\text {th }}, 2017$}

In this first meeting, the writer met the eighth grade students of SMP Deli Murni Medan and the writer was accompanied by Mam. RS (The teacher of Englis h at the school). The writer initiated the meeting by greeting and introducing herself to the students and explained the purpose of her coming to the school in order to conduct a research for her Sarjana'sthesis. The students welcomed her friendly and they were enthusiastic.

Before conducting the first cycle, the pre-test was given to measure how far the students' competence in using question tag in their daily activities. The criteria of the test which were assessed are grammar, intonation, punctuation. The sheet for this is already prepared by the writer, and the value judgement was done by two persons, the writer and the English teacher as the collaborator.After finishing the

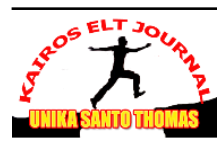


test, the writer told the students that she would meet them in the next meeting and before leaving the class the writer said "good bye"to them.

From the result of pre-test, it was found out that the students'competence in using question tag is still low and only 5 students of 35 students could pass the Minimum Mastery Criterion (KriteriaKetuntasan Minimal / KKM). So, the writer decided to teach them question tag through discussion method. There are one meeting for pre-test, three meetingsfor cyle I, and three meetings for cyle II, and one meeting for post test.

\section{Cycle I}

The following were the elaborations of cycle I:

\section{Saturday, September $16^{\text {th }}$}

Firstly, the writer entered the class, greeted the students by saying" good morning students, how are you doing?" and they answered "good morning miss, I am fine. And you?". Then the writer replied "I am great, thank you". After greeting, the writer checked the students' attendence list. Then the writer did brainstorming by asking each student some questions about the topic namely, question tag "You are a student, aren't you?"

The next step the writer explained the topic about question tags. The writer explained how to use question tag in their conversation. After explaining the topic, the writer told students that they would be divided into groups. Each group consists of six students, then writer gave them 15 up to 25 minutes to prepare their performance. When the students showed their performance, the writer observed all criteria which were assessed: grammar, intonation, punctuation and fluency.

Based on the writer's observation, the writer concluded that there were still so many mistakes in intonation, and grammar. After the students finished their test, the writer tried to correct the students' mistakes by listening, and repeating, and writing the grammar correctly.

Before clocing the lesson, the writer summarized the lesson and gave them motivation to study hard. Then, the writer said" Enough for today, and see you tomorrow" and they answered "see you Miss". Then, the writer left the class.

\section{Thursday, September $2^{\text {th }}$}

In this meeting, the writer did the actions like in the second meeting namely: asking about their conditions and then checking their attendance list. After that, the writer told the students that they would continue the topic about question tag. After the writer explained the topic the writer told students taht they would be divided into groups. Each group consists of six students, then writer gave them 15 up to 25 minutes to prepare their performance.

When the students showed their performance, the writer observed all criteria which were assessed: grammar, intonation, punctuation and fluency. The writer observed the students who performed their task. They still made a lot of mistakes in intonation and pronunciation of some words. For example about intonation, there is falling and rising intonation. They still did not know when to use rising intonation, and when to use the falling one.

Before closing the lesson, the writer summarized the lesson and gave them motivation to study hard. Then, the writer said" Enough for today, and see you tomorrow" and they answered "see you Miss". Thn, the writer left the class.

\section{Saturday, September $30^{\text {th }}$}

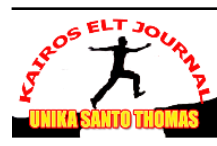


This was the last meeting in cycle I, so the writer had to ensure the students' understanding by giving a test that was called formative test cycle I.

Before giving the formative test, as usual the writer greeted the students, bysayng"good morning students, how are you doing?" and they answered " good morning miss, I am fine. And you?". Then the writer replied "I am great, thankyou". After that the writer checked their attendance list and called their name one by one.. Next, the writer told the students that they would be given formative test. Because in this meeting lasted 80 minutes, so before giving the test, the writer reviewed their lesson about 10 minutes and then gave a new topic how to make confirmation with a tag question.

\section{Cycle II}

The following were the elaborations of cycle II:

\section{Thursday, Oktober05 ${ }^{\text {th }}$}

In this meeting, the writer initiated the meeting by greeting the students, by saying "good morning students, how are you doing," And they answered "Good morning Miss, I am fine. And you"? Thenthewriter replied "I am Fine, thank you". After that the writer checked the attendance list by calling their name one by one. When the writer called students' name, the students raised his/her hand by saying an English word as "Present and I am here".

The writer started the teaching learning process by reviewing the lesson last meeting. For eample the writer asked about" Miss Lely is a teacher, isn't she?

The next step, the writer told the students that they should pay attention to the sentence and the tense, when they wanted to make q question tag. When the statement is possitive, the tag is negative, and the other way around. After explaining the topic, the writer told students, they would be divided into groups. Each group consists of six students, then writer gave them 15 up to 25 minutes to prepare their performance.

When the students showed their performance, the writer observed all criteria which were assessed: grammar, intonation, punctuation and fluency.

Before closing the lesson, the writer summarized the lesson and gave them motivation to study hard and some homework. Then, the writer anded the lesson for today, she left the class, saying good bye.

\section{Saturday, Oktober $0^{\text {th }}$}

In this meeting, the writer initiated the meeting by greeting the students, by saying "good morning student, how are you doing." And they answered "Good morning Miss, I am fine. And you"? Then the writer replied "I am Fine, thank you". After that the writer checked the attendance list by calling their name one by one. When the writer called students' name, the students raised his/her hand by " Present and I am here".

The writer started the teaching learning process by reviewing the lesson in the last meeting. For example the writer asked if the positive statement of ' $I \mathrm{am}$ pretty, ' what is the tag?

The next step, the writer told the students that they would continue the topic about question tag. The writer explained how the students used question tag in sentences and how to practice it in conversation. After explaining the topic, the writer told the students, they would be divided into groups. Each group consists of six students,

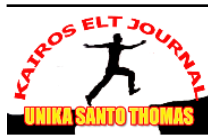


then writer gave them 15 up to 25 minutes to prepare their performance. When the students showed their performance.

Then from each group, one student came forward and the writer made them in pair.Then, they practised the question tag for example :

A: John is sick today,

B: ---------------?

So one student said the statement and the other made the tag. Each group had already prepared their sentence, and their partner would made the tag.

Before closing the lesson, the writer summarized the lesson and gave them homework and motivation to study hard. Then, the writer endedthe class and said good bye.

\section{Thursday, Oktober $0^{\text {th }}$}

In this meeting, the writer initiated the meeting by greeting the students, by saying "good morning student, how are you doing." And they answered "Good morning Miss, I am fine. And you"? Then the writer replied "I am Fine, thank you". After that the writer checked the attendance list by calling their name one by one. When the writer called students' name, the students raised his/her hand by saying "Present and I am here".

The writer started the teaching learning process by reviewing the last lesson. For eample the writer asked if the positive stantment of 'He is fine,' what is the tag?

The next step, the writer told the students that they would continue the topic about question tag. The writer explained how the students used question tag in sentences and how to practice it in conversation. After explaining the topic, the writer told students, they would be divided into groups. Each group consists of six students, then writer gave them 15 up to 25 minutes to prepare their performance.

Before clocing the lesson, the writer suuarized the lesson and gave them motivation to study hard. Then, the writer said" Enough for today, and see you tomorrow" and they answered "see you Miss". Then, the writer left the class.

\section{Saturday, Oktober $07^{\text {th }}, 2017$}

In this meeting, the writer initiated the meeting by greeting the students, by saying "good morning student, how are you doing." And they answered "Good morning Miss, I am fine. And you"? Then the writer replied "I am Fine, thank you". After that the writer checked the attendance list by calling their name one by one. When the writer called students' name, the students raised his/her hand by saying an English word as "Present and I am here".

The writer started the teaching learning process by reviewing the lesson last meeting. For example the writer asked if the negative stantment of 'Ratu doesnt like mini skirts, 'what is the tag?

The next step, the writer told the students that they would continue the topic about question tag. The writer explained how the students using question tag in sentences and how to practice it in conversation. After explaining the topic, the writer told students, they would be divided into groups. Each group consists of six students, then writer gave them 15 up to 25 minutes to prepare their performance. When the students showed their performance, the writer observed all the criteria which mentioned above.

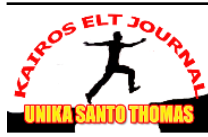


Before closing the lesson, the writer summarized the lesson and gave them motivation to study hard. Then, the writer said" Enough for today, and see you tomorrow" and they answered "see you Miss". Than, the writer left the class

\section{Post-Test:Thursday, Oktober09 ${ }^{\text {th }}$}

This was the last meeting in cycle II, so the writer had to ensure if the students competence in using question tag through discussion method improved or not by giving the post test. The wtiter greeted the students by saying"Good morning students, how are you" and they answered" good morning too miss, I am fine" Then the writer responded" I am Fine, Thank you"and the writer checked the attendance by calling their name one by one.

Next, the writer told the students that they would be given test.The writer gave the questions about question tags. The writer gave them 20 minutes up 25 minutes for practice their test about question tag.The criteria which were assessed was of the same criteria in post-test, namely grammar, intonation, punctuation and fliency. After that the students had done their perfomance, the writer motivated the students to learn more in home. Then the writer said" Enough for today dear students and see you nex time" They answerd" see you miss" Then the writer left the class.

After that, the writer found that there were still some mistakes of intonation. But the writer did not find many mistakes from the pre-test cycle I until cycle II. In this meeting, the students madebigger improvement than the previous meeting. After calculating the scores, it was found that there were 32 students who passed the Minum Mastery Criterion ( Kriteria Ketuntasan Minimal/KKM). It means that only two students who five students who could pass the KKM. In short The Discussion Method could improve the competence of the students in using question tag.

\subsubsection{The Qualitative Data}

The Qualitative datawas taken from observation sheet, field notes, and Questionnare.

\subsubsection{Observation Sheets}

Observation sheet was made by the writer to be checked by the collaborator who observed the learning process in the cycle I and cycle II. There was two observation sheets. The observation sheet I was done to see about the effective ness in using Question tags through discussion method. The observation sheet 2 was done to see about the evaluation of all concerning teaching and learning process. It an seen from the observation sheet as follow.

Table 1. Observation Sheet Cycle I

\begin{tabular}{|c|c|c|c|c|c|}
\hline Focus & \multirow{2}{*}{ Description } & \multicolumn{2}{|c|}{ Meeting I } & \multicolumn{2}{|c|}{ Meeting II } \\
\hline \multirow{3}{*}{$\begin{array}{l}\mathbf{T} \\
\mathbf{E} \\
\mathbf{A} \\
\mathbf{C}\end{array}$} & & Yes & No & Yes & No \\
\hline & $\begin{array}{l}\text { 1. The teacher comes to } \\
\text { class on time }\end{array}$ & $\sqrt{ }$ & & $\sqrt{ }$ & \\
\hline & $\begin{array}{l}\text { 2. The teacher greets } \\
\text { the students }\end{array}$ & $\sqrt{ }$ & & $\sqrt{ }$ & \\
\hline
\end{tabular}




\begin{tabular}{|c|c|c|c|c|c|}
\hline $\begin{array}{l}\mathbf{H} \\
\mathbf{E} \\
\mathbf{R}\end{array}$ & $\begin{array}{l}\text { 3. The teacher does the } \\
\text { brain stroming to } \\
\text { introduce the topic }\end{array}$ & $\sqrt{ }$ & & $\sqrt{ }$ & \\
\hline & $\begin{array}{l}\text { 4. The teacher explains } \\
\text { the material to the } \\
\text { students }\end{array}$ & $\sqrt{ }$ & & $\sqrt{ }$ & \\
\hline & $\begin{array}{l}\text { 5. The teacher uses } \\
\text { media in presenting } \\
\text { the material }\end{array}$ & $\sqrt{ }$ & & $\sqrt{ }$ & \\
\hline & $\begin{array}{llr}\text { 6. } & \text { The teacher } \\
\text { motivates } \\
\text { thestudents } \\
\text { learning }\end{array}$ & $\sqrt{ }$ & & $\sqrt{ }$ & \\
\hline & $\begin{array}{l}\text { 7. The teacher gives a } \\
\text { chance to the } \\
\text { students to ask about } \\
\text { the lesson }\end{array}$ & $\sqrt{ }$ & & $\sqrt{ }$ & \\
\hline & $\begin{array}{ll}\text { 8. The teacher } \\
\text { concludes the lesson }\end{array}$ & $\sqrt{ }$ & & $\sqrt{ }$ & \\
\hline & $\begin{array}{l}\text { 9. The teacher leaves } \\
\text { the class on time }\end{array}$ & $\sqrt{ }$ & & $\sqrt{ }$ & \\
\hline $\begin{array}{l}\text { S } \\
\text { T } \\
\text { U } \\
\text { D }\end{array}$ & $\begin{array}{l}\text { 1. The students listen } \\
\text { the teacher's } \\
\text { explanation about the } \\
\text { lesson }\end{array}$ & $\sqrt{ }$ & & $\sqrt{ }$ & \\
\hline $\begin{array}{l}\mathbf{E} \\
\mathbf{N} \\
\mathbf{T} \\
\mathbf{S}\end{array}$ & $\begin{array}{l}\text { 2. The students give } \\
\text { participation during } \\
\text { the teaching learning } \\
\text { process }\end{array}$ & $\sqrt{ }$ & & $\sqrt{ }$ & \\
\hline & $\begin{array}{l}\text { 3. The students ask the } \\
\text { teacher about the } \\
\text { unclear lesson }\end{array}$ & & $\sqrt{ }$ & & $\sqrt{ }$ \\
\hline & $\begin{array}{l}\text { 4. The students are } \\
\text { given the test by } \\
\text { teacher }\end{array}$ & $\sqrt{ }$ & & $\sqrt{ }$ & \\
\hline $\begin{array}{l}\mathbf{C} \\
\mathbf{O}\end{array}$ & $\begin{array}{l}\text { 1. The clasroom is far } \\
\text { from noisy }\end{array}$ & $\sqrt{ }$ & & $\sqrt{ }$ & \\
\hline $\begin{array}{l}\mathbf{N} \\
\mathbf{T}\end{array}$ & $\begin{array}{ll}\text { 2. } & \text { Theclassroom is } \\
\text { clean and fresh }\end{array}$ & $\sqrt{ }$ & & $\sqrt{ }$ & \\
\hline $\begin{array}{l}\mathbf{E} \\
\mathbf{X} \\
\mathbf{T}\end{array}$ & $\begin{array}{l}\text { 3. The classroom is } \\
\text { comfortable }\end{array}$ & $\sqrt{ }$ & & $\sqrt{ }$ & \\
\hline
\end{tabular}

Observation Cycle II

\begin{tabular}{|l|l|l|l|l|l|}
\hline Focus & \multirow{2}{*}{ Description } & \multicolumn{3}{|l|}{ Meeting I } & \multicolumn{2}{|l|}{ Meeting II } \\
\cline { 3 - 6 } & & Yes & No & Yes & No \\
\hline
\end{tabular}




\begin{tabular}{|c|c|c|c|c|c|}
\hline $\begin{array}{l}\mathbf{T} \\
\mathbf{E}\end{array}$ & $\begin{array}{l}\text { 10. The teacher comes to } \\
\text { class on time }\end{array}$ & $\sqrt{ }$ & & $\sqrt{ }$ & \\
\hline $\begin{array}{l}\text { A } \\
\mathbf{C}\end{array}$ & $\begin{array}{l}\text { 11. The teacher greets } \\
\text { the students }\end{array}$ & $\sqrt{ }$ & & $\sqrt{ }$ & \\
\hline $\begin{array}{l}\mathbf{H} \\
\mathbf{E} \\
\mathbf{R}\end{array}$ & $\begin{array}{l}\text { 12. The teacher does the } \\
\text { brain stroming to } \\
\text { introduce the topic }\end{array}$ & $\sqrt{ }$ & & $\sqrt{ }$ & \\
\hline & $\begin{array}{l}\text { 13. The teacher explains } \\
\text { the material to the } \\
\text { students }\end{array}$ & $\sqrt{ }$ & & $\sqrt{ }$ & \\
\hline & $\begin{array}{l}\text { 14. The teacher uses } \\
\text { media in presenting } \\
\text { the material }\end{array}$ & $\sqrt{ }$ & & $\sqrt{ }$ & \\
\hline & $\begin{array}{l}\text { 15. The teacher } \\
\text { motivates } \\
\text { thestudents } \\
\text { learning }\end{array}$ & $\sqrt{ }$ & & $\sqrt{ }$ & \\
\hline & $\begin{array}{l}\text { 16. The teacher gives a } \\
\text { chance to the } \\
\text { students to ask about } \\
\text { the lesson }\end{array}$ & $\sqrt{ }$ & & $\sqrt{ }$ & \\
\hline & $\begin{array}{l}\text { 17. The teacher } \\
\text { concludes the lesson }\end{array}$ & $\sqrt{ }$ & & $\sqrt{ }$ & \\
\hline & $\begin{array}{l}\text { 18. The teacher leaves } \\
\text { the class on time }\end{array}$ & $\sqrt{ }$ & & $\sqrt{ }$ & \\
\hline $\begin{array}{l}\text { S } \\
\text { T } \\
\text { U } \\
\text { D }\end{array}$ & $\begin{array}{l}\text { 5. The students listen } \\
\text { the teacher's } \\
\text { explanation about the } \\
\text { lesson }\end{array}$ & $\sqrt{ }$ & & $\sqrt{ }$ & \\
\hline $\begin{array}{l}\mathbf{E} \\
\mathbf{N} \\
\mathbf{T} \\
\mathbf{S}\end{array}$ & $\begin{array}{l}\text { 6. The students give } \\
\text { participation during } \\
\text { the teaching learning } \\
\text { process }\end{array}$ & $\sqrt{ }$ & & $\sqrt{ }$ & \\
\hline & $\begin{array}{l}\text { 7. The students ask the } \\
\text { teacher about the } \\
\text { unclear lesson }\end{array}$ & & $\sqrt{ }$ & & $\sqrt{ }$ \\
\hline & $\begin{array}{l}\text { 8. The students are } \\
\text { given the test by } \\
\text { teacher }\end{array}$ & $\sqrt{ }$ & & $\sqrt{ }$ & \\
\hline $\begin{array}{l}\mathbf{C} \\
\mathbf{O}\end{array}$ & $\begin{array}{l}\text { 4. The clasroom is far } \\
\text { from noisy }\end{array}$ & $\sqrt{ }$ & & $\sqrt{ }$ & \\
\hline $\begin{array}{l}\mathbf{N} \\
\mathbf{T}\end{array}$ & $\begin{array}{l}\text { 5. Theclassroom } \\
\text { clean and fresh }\end{array}$ & $\sqrt{ }$ & & $\sqrt{ }$ & \\
\hline $\begin{array}{l}\mathbf{E} \\
\mathbf{X} \\
\mathbf{T}\end{array}$ & $\begin{array}{l}\text { 6. The classroom } \\
\text { is comfortable }\end{array}$ & $\sqrt{ }$ & & $\sqrt{ }$ & \\
\hline
\end{tabular}


Observation was done during the teaching-learning process. In this observation, the writer needed a collaborator, and the collaborator in this observation was the teacher of English at the school. The observation report was based on the observation list in the cycle 1; the writer could open the class well, able in explaining the material, giving motivations and the closing was so good, event though there were some lack like; the writer could not manage the time bell and also some of the students did not pay full attention to the writer.

But the observation sheet in cycle 2 showed that the writer could do everything well like opening the class well, explaining material well, giving motivations using media living the class on time, and also the students pay full their attention and giving their participation during the teaching learning process. So, base of the result of observation, it could be concluded that students were more eager, active, interested and enthusiastic in learning English question tag.

\subsection{The Quantitative Data}

The quantitative data were taken from the result of pre-test, formative test and posttest. Before conducting the treatment, the pre-test was given to measure how far the students' vocabulary mastery. In the last meeting of cycle I, the formative test was given to measure the improvement of the students. Then, the post test was given to the students at the end of the whole cycles to measure the students' improvement after the treatment. The result of the students' score in every test can be seen from the table of score interval and the frequency as follows:

Scoring interval is found by applying this following formula.

Scoring Interval $(P)=\frac{R}{K}=\frac{X n-X 1}{1+3,3 \log n}$

Where:

The devision of distance $(\mathrm{R})=\mathrm{Xn}$ (the highest Score) $-\mathrm{X}_{1}$ (the lowest Score). In which, $\mathrm{Xn}=64$ and $\mathrm{X}_{1}=40$

The Sum of whole data $(K)=1+3,3$ logn

$\mathrm{n}=$ the number of data $\log _{(37)}=1,56$

Thus, $\mathrm{P}=\frac{64-40}{1+3,3 \log 37}=\frac{24}{1+6,17}=\frac{24}{6,17}=\frac{24}{6}=4$

Table 2. Pre-Test Score Interval

\begin{tabular}{|l|l|l|}
\hline Score Interval & Frequency & Percentage \\
\hline $40-43$ & 5 & $14 \%$ \\
\hline $44-47$ & 1 & $3 \%$ \\
\hline $48-51$ & 5 & $14 \%$ \\
\hline $52-55$ & 11 & $29 \%$ \\
\hline $56-59$ & 1 & $3 \%$ \\
\hline $60-63$ & 12 & $32 \%$ \\
\hline $64-67$ & 2 & $5 \%$ \\
\hline Total & 37 & $100 \%$ \\
\hline
\end{tabular}




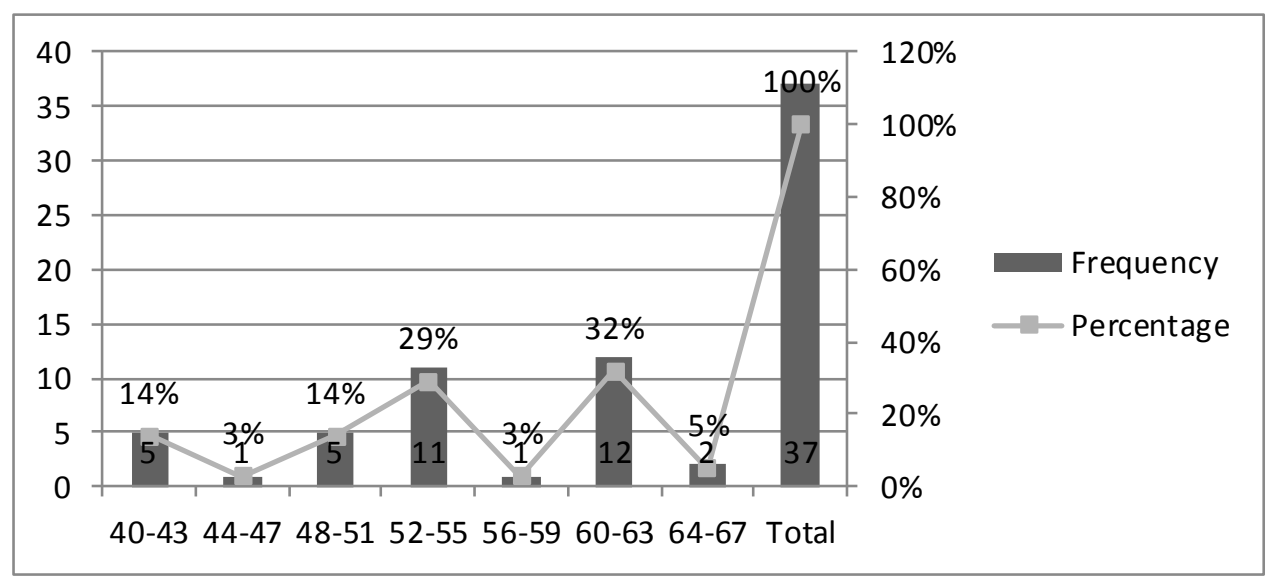

Figure 2. Histogram Pre-Test Score Interval

From the histogram of pre-test above, the highest score interval is (32\%). It means that there are 9 students who got the highest score in interval 60-63 in pre test. The lowest score interval there are 2 students in 44-47(3\%) and 56-59 (3\%) score interval, there are 2 students who got score in interval 64-67 (5\%)in the pre test. In addition, there are $10(16 \%)$ students who got score in interval 40-43 and 48-51. Then, there are 11 (29\%) students who got 52-55.

The quantitative data were taken from the result of pre-test, formative cycle 1 , and post-test cycle 2 . Before conducting the first cycle, the pre-test was given to measure how far the students competence in using question tag through discussion method. From the result of pre-test it was found that the 37 students did not passed the Minimum Mastery Criterion (KriteriaKetuntasan Minimum).

Scoring Interval $(P)=\frac{R}{K}=\frac{X n-X 1}{1+3,3 \log n}$

Where:

The devision of distance $(\mathrm{R})=\mathrm{Xn}$ (the highest Score) $-\mathrm{X}_{1}$ (the lowest Score). In which, $\mathrm{Xn}=78$ and $\mathrm{X}_{1}=60$

The Sum of whole data $(K)=1+3,3$ logn

$\mathrm{n}=$ the number of data $\log _{(37)}=1,56$

Thus, $\mathrm{P}=\frac{78-60}{1+3,3 \log 37}=\frac{18}{1+6,17}=\frac{18}{6,17}=\frac{18}{6}=3$

Table 3. Formative Test Score Interval

\begin{tabular}{|l|l|l|}
\hline Score Interval & Frequency & Percentage \\
\hline $60-62$ & 3 & $8 \%$ \\
\hline $63-65$ & 1 & $3 \%$ \\
\hline $66-68$ & 5 & $14 \%$ \\
\hline $69-71$ & 12 & $32 \%$ \\
\hline $72-74$ & 7 & $19 \%$ \\
\hline $75-77$ & 4 & $10 \%$ \\
\hline $78-80$ & 5 & $14 \%$ \\
\hline Total & 37 & $100 \%$ \\
\hline
\end{tabular}




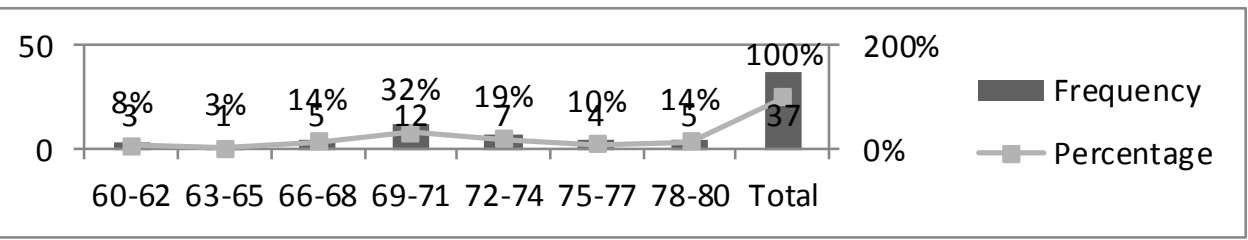

Figure 3. Histogram of Formative Test

From the histogram of formative -test above, the highest score interval is 69-71 $(32 \%)$. It means that there are 12 students who got the highest score in interval 6971 in pre test. The lowest score interval is 63-65, there is one student who got (3\%)score. In addition, there are $3(8 \%)$ students who got score in interval 60-62. Then, there are $4(10 \%)$ students who got $75-77$, there are $5(14 \%)$ students who got score in interval 66-68 and 78-80. In addition, there are $7(19 \%)$ students in interval 72-74.

At the end of the meeting of cycle 1, the formative was given to measure the improvement of the students. From the result of formative there were 9 students of 37 students who passed the Minimum Mastery Criterion was 75 .

Scoring Interval $(P)=\frac{R}{K}=\frac{X n-X 1}{1+3,3 \log n}$

Where:

The devision of distance $(\mathrm{R})=\mathrm{Xn}$ (the highest Score) $-\mathrm{X}_{1}$ (the lowest Score). In which, $\mathrm{Xn}=96$ and $\mathrm{X}_{1}=64$

The Sum of whole data $(K)=1+3,3$ logn

$\mathrm{n}=$ the number of data $\log _{(37)}=1,56$

Thus, $P=\frac{96-64}{1+3,3 \log 37}=\frac{32}{1+6,17}=\frac{32}{6,17}=\frac{32}{6}=6$

Table 4. Post-Test Score Interval

\begin{tabular}{|l|l|l|}
\hline Score Interval & Frequency & Percentage \\
\hline $64-69$ & 3 & $8 \%$ \\
\hline $70-75$ & 2 & $5 \%$ \\
\hline $76-81$ & 17 & $46 \%$ \\
\hline $82-87$ & 5 & $14 \%$ \\
\hline $88-93$ & 7 & $19 \%$ \\
\hline $94-99$ & 3 & $8 \%$ \\
\hline Total & 37 & $100 \%$ \\
\hline
\end{tabular}

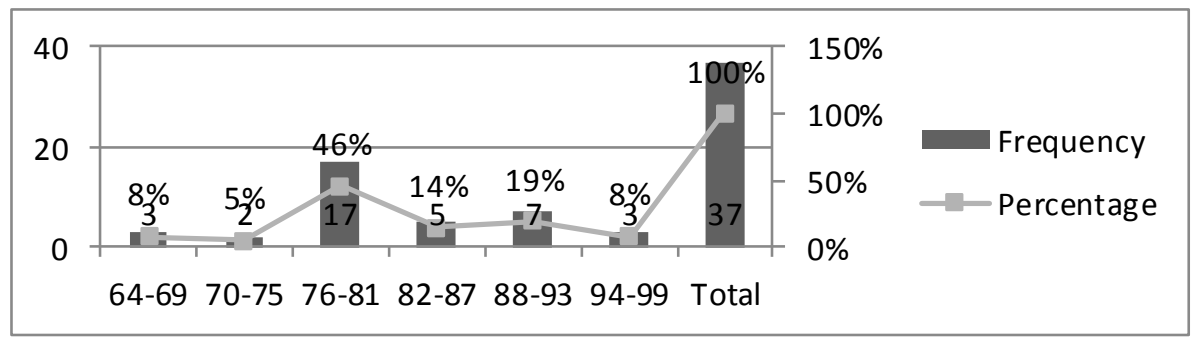

Figure 4. Histogram of Post-Test Score Interval 
From the histogram of post test, the highest score interval is $76-81(46 \%)$. It means that there are 17 students got the highest score. The lowest score interval is $70-75$, there are $2(5 \%)$ students. In addition, in the post test there are $3(8 \%)$ students who got score in interval 64-69 and 94-99. Then, there are 5 (14\%) students who got score in interval 82-87. There are $7(19 \%)$ students who got score in interval 8893.

Next at the and of the meeting of cycle 2 the post-test given to measure the students improvement after the treatment. From the result of post test, it was found out that there were 32 students of 37 students who passed the KKM. It means that only five students could not passed the KKM.

To find out the students mean score in each test the writer applied the following formula.

$$
X=\frac{\sum \mathrm{X}}{\mathrm{N}} \mathrm{X} 100
$$

So, from the formula above the result of the students mean score was shown as follows:

a. In the pre-test the total score of the students was $\frac{1998}{37}=54 \%$

b. In the formative cycle 1 the total score of the students was $\frac{2630}{37}=71,08 \%$

c. In the post-test cycle 2 , the total score of the students was $\frac{3004}{37}=81,18 \%$

From the result of the studentsscore above it could be concluded the students mean score improved it could be seen from the score from pretest up to post test cycle 2 in pre-test the students mean score was 54, while the students mean score in formative cycle 1 was 71,08 . So, increased point was $17.08 \%$ and post-test was $81.19 \%$. The increasing point was 27,19 .

\subsection{The Research Findings}

The findings of the research showed that discussion method could improve the students competence in using question tag. The improvement could be seen from the students mean score from the pre-test II. The students mean score in pre-test was 54, the means formative cycle I was 71.08, and the mean of post test cycle II was 81.19. The qualitative data also showed that students became more active, enthusiastic, comfortable, and more eager in practicing their competence in using question tag. It means that discussion method can increase the learning spirit of the students and make them to able aplicationin their daily activities.

\subsection{Discussion}

In fact, discussion method in using question tag is very interesting because all of students can practice their competence in using question tag in every activity. All of students had activities one by one so the students can be creative when they perform in front of the class. Before applying the method in using question tag most of students did not understand about question tag. The writer observed that the students did not pay attention to their teacher even when the writer was seriously teaching them about question tag.

After applying discussion method the students became more active in practicing their competence in using question tag. This method involved every student to participate in their group. They disccoused the material among then before they presented it in front of the class. They practised the question tag in pairs,

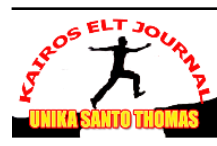


one said the statement with various subjects tenses and predicate, and the other made the tag. The students' mean score in formative cycle 1 improved. After finishing cycle 1 the writer did the cycle 2 and the result showed the students score also improved.Therefore, from the result it could be said that discussion method in using question tag could improve students' competence in using question tag successfully. The mean score improves from the pretest, formtive test to the posttest.

\section{CONCLUSION}

Based on the result of the research that was conducted at the eight grade students of SMP Deli Murni Medan, the writer inferred that teaching the eight grade students' competence in using question tags thorugh discussion method was effective and could improve students' competence in using question tags. It can be proved through several data such as, observation sheet and field notes which showed students enthuciasm and actively participated in learning process.

After analyzing and presenting data in the previous chapter, the writer makes conclusions as follows:

1. Discussion Method can improve students' achievement in increased students' competence in using question tags. The students' mean score from pre-test to post-test. The students' mean score of pre-test is 54 , formative test is 71,08 and post-test is 81,19. Meanwhile, the students score percentage who passed Minimum Mastery Criteria (KriteriaKetuntasan Minimum [KKM]) from pretest is $54 \%$, the formative test $71.08 \%$ and post-test $81,19 \%$. The students' score and percentage continuously increased each test. Therefore, it is concluded that Discussion Methodcan improve students' achievement in using question tags.

2. The students'agreed that the application of Discussion Method could improve their achievement in using question tags. The analysis of qualitative data showed that the students were more active and enthusiastic in learning question tag after Discussion Method applied.

\section{BIBLIOGRAPHY}

Azar, S.B. and Hagen. A.S. 1989:16 Understanding and Using English Grammar $4^{\text {th }}$ Edition. New

York: Pearson Longman.

Aziz, Fathul. 2013. Speaking Skill by Using Discussion Method. A Thesis unpublished. Universitas

Islam Makasar

Badache, Lynda. 2015. Discussion as An Active Learning in EFL. Eouropean Scientific Journal, 11(16), 231-235.

Burns, Anne. 2010. Doing Action Research in English Language Teaching: A Guide for

Practitioners. New York: Routledge.

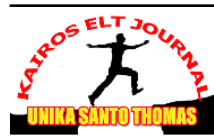


KAIROS ELT JOURNAL, Vol. 3 No. 2 Agustus 2019

Copyright@2019, ISSN: 2580-4278

Byrd and Benson. 2001. Applied English Grammar. Thomson:Thomson Learning, Inc.

Diane, Larsen. 2003. Teaching Grammar: from Grammar to Grammaring. Boston: Heinle.

Dushi, Gauri. 2012. What are the Advantages of Discussion Method of Teaching. Accessed from www.preservearticles.com. .

Fuchs, Marjorie and Margareth Bonner. 2000. Focus on Grammar. London: Addison Wesley Longman.

Frank, Marcella. 1972. Modern English a Practical Reference Guide. New Jersey: Prentice Hall,

Inc.

Geoffrey, Leech. et.al. 2000. English for Today. New York: Macmilan Press.

Latchanna, Gara and Dagnew, Asrat. The Problems and Prospects of the Visually Challenge. A

Case Study in Srikakulam Distric, 2(5), 103-105.

Penny, Ur. 1991.Grammar Practice Acrivity: A Practical Guide for Teachers. New York:

University Press.

Schwartz, Michelle. 2013. Discussion as A Teaching Technique. Canada: Ryerson University.

Soars and Soars. 2000.New Headway English Course: Intermediate Workbook (2nd ed.). Oxford:

Oxford University Press.

Spring, Andersen.1989.Sentence Types and Functions. New York: Spring Publication.

Sudjiono, Anas. 2008. Pengantar Statistik Pendidikan. Jakarta: Pt. Raja Grafindo Persada.

Thomson. J. A. and Martinet. 1993.A Practical English Grammar $4^{\text {th }}$ Edition.

Oxford: Oxford

University Press.

Wallace, M.J. 1998.Action Research for Language Teacher. Cambridge: Cambridge University 
KAIROS ELT JOURNAL, Vol. 3 No. 2 Agustus 2019

Copyright@2019, ISSN: 2580-4278

Press

Westwood, Peter. 2008. What Teachers Need to Know about Learning Difficulties. Victoria: ACER

Press.

Wren, P.C. and Martin, H. 1989. High School English Grammar and Composition. New Delhi:

Ram Nagar

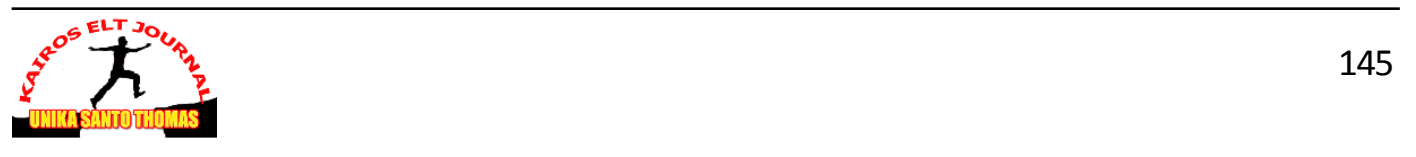

